Joshua Preiss*

\title{
Milton Friedman on Freedom and the Negative Income Tax
}

DOI 10.1515/bis-2015-0008

Published online October 14, 2015

Abstract: In addition to his Noble Prize-winning work in economics, Milton Friedman produced some of the most influential philosophical work on the role of government in a free society. Despite his great influence, there remains a dearth of scholarship on Friedman's social and political philosophy. This paper helps to fill this large void by providing a conceptual analysis of Friedman's theory of freedom. In addition, I argue that a careful reading of his arguments for freedom ought to lead Friedman, and like-minded liberals and libertarians, to give absolute priority to his negative income tax proposal. A substantial basic income furthers effective economic freedom (on Friedman's own understanding), redeems his central claim that markets enable cooperation without coercion, and enables him to address his lifelong interlocutors by mitigating concerns for the ways in which economic dependence and inequality undermine both freedom and democratic legitimacy.

Keywords: negative income tax, freedom, ethics and economics, liberalism, republicanism

\section{Introduction}

After John Maynard Keynes, Milton Friedman is arguably the most influential economist of the twentieth century. Friedman did not restrict his writing to technical questions in economic theory. Instead, he produced some of the most influential philosophical work on the role of government in a free society. This work, perhaps more than any other, provides the central and agenda-setting talking points for so-called neo-liberal political and economic reforms championed by the Republican party in the U.S., the Conservative Party from the time of Thatcher in the United Kingdom (Childs, 2006; Reitan, 2003), ${ }^{1}$ and

\footnotetext{
1 See also http://www.telegraph.co.uk/news/uknews/1534387/Thatcher-praises-Friedman-her-free dom-fighter.html. The work of F.A. Hayek and others, of course, has also been quite influential in these contexts. More on Hayek below.
}

Corresponding author: Joshua Preiss, Department of Philosophy, Minnesota State University, Armstrong Hall, Mankato, MN 56001, USA, E-mail: joshua.preiss@mnsu.edu 
throughout the world, even by agencies, such as the IMF, that Friedman himself opposed. ${ }^{2}$ Despite this influence, there remains a dearth of scholarship on Friedman's social and political philosophy, particularly among philosophers and political theorists. Friedman's work on freedom is worth engaging for a number of reasons. First, Friedman has a contribution to make to philosophical debates on freedom, and the link between political and economic freedom. He wisely and astutely challenges philosophers, economists, and policy-makers who treat the ethics and politics of political and democratic institutions in isolation from economic institutions. Second, his arguments are not merely empirical. He makes a number of conceptual distinctions, and relies upon controversial notions of freedom, that open his claims up to criticism, even in the event that he is largely correct on the economic facts of the matter. Those who utilize Friedman's arguments (or parallel arguments) in good faith - to convince those not already committed to Friedman's policy prescriptions - must grapple with these issues, to avoid the charge that their use of Friedman's arguments is just a cynical appropriation of the rhetorical cache that Friedman's economic credentials provide.

For critics, philosophical ignorance, in this case, entails political impotence. Philosophical work is essential to engaging and redirecting a public debate that revolves around Friedman's empirical authority, rather than the conceptual foundations of the views that he uses his empirical work to bolster. In the conclusion of Free to Choose, Friedman writes "fortunately, the tide is turning," back to "the tide of opinion toward economic freedom and limited government that Adam Smith and Thomas Jefferson did so much to promote," and which "flowed strongly until late into the nineteenth century." As such, those who propose further government intervention "can no longer arouse enthusiasm among the young who now find the ideas of Adam Smith and Karl Marx far more exciting than Fabian socialism or New Deal liberalism" (Friedman \& Friedman, 1980, p. 284). Twenty-two years later, in the preface to the Fortieth Anniversary Edition of Capitalism and Freedom, Friedman has turned from cautiously optimistic to positively triumphant, as the ideas he championed have taken hold not only in "the United States and Great Britain" but also "the other Western advanced countries ... In all of these countries pressure today is toward giving markets a greater role and government a smaller one ... and the change of opinion has had an even more

2 Such reforms include financial deregulation, opposition to the minimum wage, the privatization of national industries and public goods, the elimination social security and other forms of social insurance, tax cuts, opposition to "redistributive" policies, and more generally institutional attempts to promote greater economic equality. http://www.wsj.com/articles/SB116369744597625238 See Harvey (2007) for a critical history and analysis of neoliberalism. 
dramatic effect in the formerly underdeveloped world" (Friedman, 2002, p. viii). Friedman does not oversell the impact of these changes.

Given this impact, it is imperative to critically examine the philosophical justification provided by arguably the most prominent proponent of these changes. This paper provides such a conceptual analysis of Friedman's theory of freedom. This work is essential to any debate concerning what ways, and under what conditions, Friedman's influential proposals actually further the freedom of individuals whose choices are structured by these new "rules of the game." Finally, a careful reading of his arguments, I contend, ought to lead Friedman to give absolute priority to his negative income tax proposal. A substantial negative income tax furthers effective economic freedom, and helps to redeem Friedman's central claim that markets enable cooperation without coercion. Perhaps most importantly, it enables Friedman to address many of the concerns of his lifelong interlocutors, allowing like-minded liberals and libertarians to make their compelling case for freedom as economic non-interference in a way that mitigates (rather than simply ignores) liberal, republican, and democratic concerns for the ways in which economic dependence and inequality undermine both freedom and legitimacy.

\section{Effective freedom vs. freedom as non-interference}

The primary targets for Friedman's philosophy of freedom are so-called liberals, progressives, deliberative democrats, and "democratic socialists" who, while they value democratic and political freedoms, don't see these cherished freedoms as in any way related to economic freedom. In response to these targets, Friedman argues that capitalism is a necessary, but not sufficient, condition for political freedom. Not every capitalist society has political freedom, but every democratic society with substantial political freedom is capitalist. Friedman's arguments for these claims are both conceptual and historical. "History speaks with one voice," he reasons, "on the relation between political freedom and free markets” (Friedman, 1962, p. 10). From this history, the United States and Great Britain in the nineteenth Century are Friedman's exemplars. He writes,

The combination of economic freedom and political freedom produced a golden age in both Great Britain and the United States in the nineteenth century. The United States prospered even more than Britain. It started with a clean slate: fewer vestiges of class and status; fewer government restraints; a more fertile 
field for energy, drive, and innovation; and an empty continent to conquer (Friedman \& Friedman, 1980, p. 3).

In order to assess this central claim, it is necessary to know which societies Friedman counts as capitalist (as opposed to socialist, or some other form of economy). Such assessments also depend upon what he means by "political freedom." In truth, he isn't always clear about what he means by political freedom, or which political freedoms capitalism protects. Friedman endorses freedom of association (Friedman, 1962, p. 115) and, citing Jefferson, democratic freedom and "widespread participation in government" (Friedman \& Friedman, 1980, p. 130). The one example he discusses in detail is the relationship between capitalist political economy and freedom of speech and freedom of the press. His argument runs as follows. As both Friedman and his interlocutors grant, political freedom, and a well-functioning democracy, require the ability of criticize existing institutions. Friedman adds that critics need to be able to have their voices heard, which requires that one have access to the media. This is not a problem in capitalist societies because private individuals own the media. In short, two things are essential for freedom of speech: (1) having access to the media and (2) being able to express one's views without losing one's ability to earn a living. He claims that under socialism, where the state controls the media and all jobs, the government can deny critics access to the media and it can intimidate critics by threatening to fire them. Under capitalism, the government doesn't control the media and can't deny you access to the media. Even unpopular causes, he continues, can find rich patrons who can finance media time for these unpopular causes so that they can be heard. In addition, the government can't intimidate you by threatening to make you unemployed, because you have many different employers to choose from and you also have the option to be self-employed (Friedman, 1962, Chapter 1). The diffusion of power and authority under capitalism protects people's ability to express themselves. More generally, it allows them to shape (and thereby check) government's impact on their day-to-day lives.

Friedman's account of freedom of speech differs from the more rightsoriented accounts of freedom expressed by libertarians like Robert Nozick. Nozick famously understands rights as side-constraints on the actions of others. They set limits on what other agents (including agents of the government) can do to an individual, even in the pursuit of valuable goals such as social justice or economic growth (Nozick, 1974). With respect to a right to speech, this means that the government doesn't arrest those who speak their mind. Friedman does not deny, however, that citizens in a socialist society might have a political or constitutional right to freedom of speech. He argues that such a right would be meaningless without the means to make your views widely known. The meaningful exercise of freedom of expression requires access to the media. Also, 
substantive or effective freedom of speech is necessary as a check on government power. For economic freedom to be a check on political power, citizens must not only not be interfered with for speaking their mind. ${ }^{3}$ They must also have the resources to make use of their political right to freedom of speech. ${ }^{4}$

This argument also distinguishes Freidman's understanding of freedom from F.A. Hayek's. Hayek argues that among the many "confusions of individual liberty with different concepts denoted by the same word" the most dangerous is the "use of 'liberty' to describe the 'physical ability to do what I want,' the power to satisfy our wishes, or the extent of the choice of our alternatives" (Hayek, 1960, p. 65). For Hayek, freedom is fundamentally about "social relations," as opposed to freedom from natural or physical obstacles. Nonetheless, his arguments suggest that Hayek, in direct opposition to Friedman, does not see great differences in power between those in society as a threat to individual liberty. In fact, this "identification of liberty with power" will cause "no end to the tricks by which people can be exhorted in the name of liberty to give up their liberty" (Hayek, 1960, pp. 65-66). For Friedman, on the other hand, freedom of speech requires the economic power to make such speech be heard. It is this way that the economic power of individuals in a capitalist society can serve a check on government's attempt to limit our political liberty.

Friedman's account of freedom of expression has much more in common with Amartya Sen than with Hayek or Nozick. Sen urges us to see development as the "process of overcoming unfreedoms" (Sen, 1999, p. 33). This orientation forces us to distinguish welfare from freedom, and to distinguish process freedom from opportunity freedom. Freedom involves both the processes that allow freedom of actions and decisions, and the actual opportunities that people have, that is, their "ability to achieve ... what they value or have reason to value" given their personal and social circumstances (Sen, 2002, p. 585). Unfreedom can arise either through inadequate processes (such as the violation of voting privileges and other political or civil rights) or through a lack of opportunities to achieve what people minimally would like to achieve (including the absence of such elementary opportunities as the capability to escape premature mortality of preventable morbidity or involuntary starvation) (Sen, 1999, 2002, 2009).

3 See (Lomasky, 1987) for a libertarian account of basic rights that prioritizes freedom as noninterference.

4 In fact, at times Friedman understands property rights themselves in terms of their instrumental value. Unlike other monopolies, he reasons, "in both patents and copyrights there is clearly a strong prima facie case for establishing property rights" (Friedman, 1962, p. 127). The length of such property rights, however, "are not a matter of principle. They are matters of expediency to be determined by practical considerations" (Friedman, 1962, p. 128). Clearly Friedman is a very different sort of libertarian than Robert Nozick. 
In Sen's terms, the ability to influence public opinion through use of the media would count as opportunity freedom. As Friedman argues, even if a socialist state granted citizens the process freedom of expression (via a constitutional right) such freedom would be meaningless if an individual either lacked assess to media (which was government owned) ${ }^{5}$ or, lacking other possibilities, depended upon the government as their employer. Friedman does not argue, as Sen does, that governments and international organizations ought to understand effective freedom as the primary goal of development. Nonetheless, in his only detailed discussion of this central claim, that economic freedom protects and enables political freedom, he affirms a positive or effective understanding of freedom that distinguishes him from theorists who conceive of freedom primarily in terms of non-interference. A capitalist society, according to his reasoning, should be favored precisely because it safeguards such effective freedom in both the economic and the political sphere.

Moving from freedom of expression to economic freedom, notice also that many monopolies don't threaten economic freedom as non-interference. ${ }^{6}$ Due to economies of scale, monopolies may arise according to processes that libertarians such as Nozick would label perfectly just. Friedman steadfastly opposes monopolies, however,' arguing that "exchange is truly voluntary only when nearly equivalent options exist. Monopoly implies the absence of alternatives and thereby inhibits the effective freedom of individuals" (Friedman, 1962, p. 28). Once again, Friedman stands in direct opposition to Hayek, who claims that among the greatest threats to freedom is to confuse it with "the extent of the choice of our alternatives" (Hayek, 1960, p. 65). While Hayek's arguments for freedom (like Friedman's) are primarily consequentialist, and his consequentialism also provides a basis for opposing monopolies (as they are likely to lead to market failures), he rejects any attempt to understand economic freedom either in terms of an individual's ability to achieve or acquire what she desires or in terms of the number of options from which she is able to choose. Such understandings represent dangerous confusions of liberty with other concepts that use the same word. According to this reasoning, monopolies may hinder welfare, but they do not do so because they make individuals less free. By contrast, political freedom and economic freedom, for Friedman, concern not only what Isaiah Berlin (1958,

\footnotetext{
5 See also Friedman's criticism of the BBC (Friedman, 1962).

6 Patents protected by legal sanction, however, clearly do threaten economic freedom as noninterference.

7 With the exception of natural or technical monopolies (Friedman, 1962, pp. 28-30). In point of fact, Friedman, citing colleagues Nutter (1951) and Stigler (1949), believes that monopolies are relatively rare and ineffectual in the United States. More on freedom and monopoly below.
} 
1969) calls issues of negative liberty or what Nozick calls side-constraints on interference, but also substantive or effective freedom. In the case of freedom of speech, effective political freedom requires the resources to make your speech heard. In the case of consumer choice, effective economic freedom requires the availability of a number of "nearly equivalent” options. Friedman shares Sen's concern for both opportunity freedom and process freedom.

\section{Democratic freedom and inequality}

Like his democratic interlocutors, Friedman recognizes that an essential freedom that all individual citizens possess is the freedom to shape the laws and institutions that structure our collective and individual lives. Friedman forcefully argues, in addition, that economic liberty safeguards our political liberty, including the liberty to participate in a democracy. Such freedom is essential since, as he notes, citizens should not and cannot avoid collectively using government to accomplish things we are unable to accomplish as individuals (Friedman, 1962). More often than not, however, Friedman's discussion of important democratic freedoms is paired with the fear that "any such use is fraught with danger" that government will become a "Frankenstein that will destroy the very freedom we establish it to protect” (Friedman, 1962, p. 2). For this reason, the use of government should generally be avoided. ${ }^{8}$ He reasons that,

By relying primarily on voluntary co-operation and private enterprise, in both economic and other activities, we can insure that the private sector is a check on the powers of the governmental sector and an effective protection of freedom of speech, of religion, and of thought (Friedman, 1962, pp. 2-3).

Liberals, Friedman continues, are "suspicious of assigning to government any functions that can be performed through the market, both because this substitutes coercion for voluntary cooperation in the area in question and because, by giving government an increased role, it threatens other areas" (Friedman, 1962, p. 39). Such phraseology, unfortunately, encourages readers to identify market decisions as voluntary, regardless of how extreme the inequalities and economic concentrations of power in the modern world economy get to be. It also suggests that democratic decisions, however equally distributed democratic power is, are fundamentally coercive.

8 Friedman's skepticism of the efficacy of democracy parallels that of James Buchanan and Gordon Tullock in The Calculus of Consent (Buchanan \& Tullock, 1962) which, perhaps not coincidentally, was published the same year as Capitalism and Freedom. 
Almost without exception, democratic theorists perceive large economic inequalities as a potential threat to citizens' democratic freedom. Proponents of democracy do not, as Friedman frequently puts it, hold a prior normative commitment to "equality of outcomes." Instead, they recognize that economic inequalities often lead to political inequalities (Bartels, 2008; Forst, 2011; Gutmann \& Thompson, 1998; Habermas, 1992). Friedman claims that a happy bi-product of a focus on liberty will be greater equality. ${ }^{9}$ Nonetheless, Freidman simply ignores of the link between democratic freedom and economic power, showing little concern for the ways in which economic inequality can undermine both freedom and legitimacy. Indeed, he opposes the progressive taxation that the legislatures of most capitalist societies utilize to promote more equal citizenship. Such taxation, he argues, hinders the effectiveness of market price in driving efficient allocation of resources. ${ }^{10}$

9 He writes, "A society that puts equality - in the sense of equality of outcome - ahead of freedom will end up with neither equality nor freedom. The use of force to achieve equality will destroy freedom, and the force, introduced for good purposes, will end up in the hands of people who use it to promote their own interests. On the other hand, a society that puts freedom first will, as a happy by-product, end up with both greater freedom and greater equality" (Friedman \& Friedman, 1980, pp. 148-149).

10 He writes, "However we might wish it otherwise, it simply is not possible to use prices to transmit information and provide an incentive to act on that information without using prices to also affect, even if not completely determine, the distribution of income" (Friedman \& Friedman, 1980, p. 23). Moreover, when discussing the ways in which monopoly power may threaten our economic freedom, he argues that, “[beyond government created monopolies] the most important and effective step toward the reduction of monopoly power would be extensive reform of the tax laws. The corporate tax should be abolished. Whether this is done or not, corporations should be required to attribute to individual stockholders earnings which are paid out as dividends ... Few measures would do more to invigorate capital markets, to stimulate enterprise, and to promote effective competition'” (Friedman, 1962, p. 132). Such tax reforms, treating corporate profits as individual earnings, would make American markets far more competitive, and therefore further both efficiency and economic freedom. So why haven't they been adopted? Friedman's answer is progressive taxation. He continues, "of course, so long as the individual income tax is highly graduated as it is now, there is pressure to find devices to evade its impact. In this way as well as directly, the highly graduated income tax constitutes a serious impediment to the efficient use of our resources" (Friedman, 1962, p. 133). The implication that if you simply lower the top tax rates, then owners of multinational corporations will stop trying to avoid tax is, with the benefit of the past 50 years of history, dubious at best. Ultimately, Friedman proposes a flat tax with corresponding elimination of loopholes (Friedman \& Friedman, 1980, pp. 306-307) to be done via constitutional amendment because of the challenges of achieving (and maintaining) such a bargain through the normal legislative processes. Whether such a proposal would be more or less regressive than America's nominally progressive but loophole-ridden present tax code is a matter for debate. 
Friedman is correct that both Adam Smith and Thomas Jefferson saw concentrated government power as a potential, and potentially great, danger (Friedman \& Friedman, 1980, p. 4). ${ }^{11}$ However, it is not only government power that presents such danger. Indeed, Friedman himself clearly recognizes the link between individual liberty and concentrations of power, writing that "the greatest threat to human freedom is the concentration of power, whether in the hands of government or anyone else” (Friedman \& Friedman, 1980, p. 309). His analysis, however, wholly ignores non-governmental sources of power. All of his examples, including the oil executive who feels uncomfortable questioning environmental policy, concern the concentration of power in the hands of government. After noting the official corporate tax rate of $48 \%,{ }^{12}$ Friedman uses this fact to explain why corporate power, unlike government power, is not something the liberal ought to fear. In the first episode of the PBS series that led to the publication of Free to Choose, Friedman claims "there was a time when corporations were powerful," but they are "now a beleagured minority."

The one exception is the case of monopoly, which Friedman argues undermines our effective economic freedom. Perhaps for this reason, his discussion of corporate power is limited to concerns that corporations will attain an enterprise monopoly of a given market. Unlike government and government-supported monopoly and, to a lesser (but still significant) extent the monopoly of labor markets by unions and guilds, corporate power is not to be feared. Why? Because in practice it is difficult for firms to monopolize a given industry or collude to fix prices for more than a very short period (Friedman, 1962, pp. 119-125). While "the governmentally operated or supervised sector has of course grown greatly over the past half-century or so," he writes, "within the private sector ... there appears not to have been any tendency for the scope of monopoly to have increased and it may well have decreased" (Friedman, 1962, p. 122). Friedman may or not be correct on the difficulty for a given firm or group of firms to exert monopolistic power in a given market, or to collude to set prices. None of this speculation, however, says anything about the ability and willingness of representatives of corporations to reconfigure markets and public policy to the benefit of managers and primary shareholders of corporations.

What, if anything, justifies this omission? Friedman's best defense is to point to his picture of an ideal society. In a 1978 lecture at Kansas State University, Friedman proposes, "to dream an ideal, a constitutional amendment

11 More on Smith and Jefferson below.

12 The United States corporate tax code is now 35\%, nominally among the highest rates in the world. However, it has become so ridden with loopholes that it fails to provide the sort of revenues that it has in the past (Leonhardt, 2011). 
that forbids Congress from imposing tariffs" and "similar measures to keep down the size and scope of government." Such an ideal, he argues, would keep "special interests" from dominating political discourse (Friedman \& Friedman, 1980, pp. 290-294). In Friedman's ideal society, on this reasoning, massive democratic inequality would in fact be unproblematic. In a society where the government is small, and largely isolated from the economic arena, the rich and powerful would have little reason to interfere with the democratic process.

On this issue, Friedmanite liberals, like their Rawlsian counterparts, face the challenge of connecting this theory of an ideal society with the less-than-ideal status quo. To be clear, the point is not that Friedman is an ideal theorist in the Rawlsian sense. Instead, it is essential to highlight that even if this vision of a state with little government intervention in the economy is a worthwhile ideal, Friedman and his supporters need to grapple with the ways in which economic inequality leads to democratic inequality in the less than ideal state (on his terms) in which government is more involved in our social and economic lives. In the context of the United States, ${ }^{13}$ where wealth and corporate ownership are very highly concentrated (Alverado, Atkinson, Piketty, \& Saez, 2013; Mischel, Bivens, Gould, \& Shierholz, 2012; Piketty, 2013; Piketty and Zucman 2015), economic inequalities lead to dramatically unequal democratic freedom. Indeed, many argue that corporate power and influence now threaten to

13 On the one hand, putting his claims in historical context makes Friedman's omissions less glaring. In 1962, the year that Capitalism and Freedom was published, Friedman could look around and see an American society of broadly shared economic growth, where unions and other government-supported institutions served as countervailing powers to massive corporations (Galbraith, 1952). Labor's share of the fruits of production, moreover, was at a historic high (Piketty, 2013). The largest of these corporations, in turn, faced comparatively less competition, produced domestically, and relied upon the growing wealth of the average worker in order to sell their goods. In such a context, Friedman could with some justification claim that corporate power posed comparatively little threat to the democratic freedom of the average citizen. On the other hand, the adoption of Friedman's proposals may in fact have contributed to the very changes that make his omissions more glaring in the present context. The political economy of the United States today, an economy Robert Reich calls "Supercapitalism," poses a very different set of threats to the liberty of citizens (Reich, 2007). Prosperity is not shared - with nearly all of the benefits of economic growth in the past 30 years going to the wealthiest $5 \%$, who also possess an unprecedented share of American wealth. Labor unions and other institutions no longer form a countervailing power to increased corporate dominance of American society and American democracy. It is in this context where Friedman's conflation of different sorts of freedom, and his tendency to ignore certain forms of freedom when they conflict with his political ends, cast further doubt on the neoliberal reforms that Friedman and his followers recommend (more below). These reforms threaten to exacerbate supercapitalism's threat to the political freedom of citizens in democratic societies. 
drown out and overwhelm other interests, and discussion of the public good. ${ }^{14}$ In the present state of affairs, such inequalities allow the powerful to restructure American political economy for the benefit of a small minority of U.S. citizens, threatening the liberty of those less powerful in the process. To be sure, Friedman, like many of his critics, frequently expresses concern for the influence of "special interests" in American politics. Perhaps he would also bemoan the influence of economic elites in the political process, and attempts to restructure the "rules of the game" to their benefit. Politically, however, the pressure for these changes needs to be combated by the some countervailing force, such as a healthy democracy in which wealth plays less of a role, or a political economy where benefits and burdens are more evenly distributed.

\section{A new "Absolute Priority" for libertarians or Friedmanite liberals}

Friedman does not use the term absolute priority, or claim to give a particular freedom absolute priority. Nonetheless, a careful analysis of his writings suggests such a priority: freedom as economic non-interference. Friedman gives priority to freedom as economic non-interference in every case where it trades off with other values, including other senses of freedom. In a dramatic example of such priority, Friedman advocates an economic bill of rights (Friedman \& Friedman, 1980, pp. 299-301), whereby democratic societies limit their ability to address various social issues (including concerns about justice) in order to safeguard the liberty of individuals within those societies to spend money as they wish. More often than not, Friedman simply denies that economic freedom as non-interference ever trades off with other freedoms. This orientation undoubtedly contributes to his belief that nineteenth century United States was the golden age of liberty (Friedman \& Friedman, 1980, p. 2). Such claims marginalize the impact of a lack of democratic freedom of the massive amounts of the population who were disenfranchised. Even in terms of economic freedom, it suggests that freedom entails a lack of government interference. As a result, it ignores the massive poverty of a population (many of which lacked effective freedom) the large trusts of the late nineteenth century, a working population that had little freedom not to work in an unsafe work environment, to support their family without child labor, and so on. It ignores the cultural and religious recognition that provides members of minority groups greater freedom

14 www.publicintegrity.org 
to participate as peers in civil society. It ignores republican concerns that rapid industrialization threatens freedom as non-domination. Unless we only recognize the value of negative freedom (in Berlin's sense), and even then only negative freedom from a particular sort of agent (government), it is difficult to see how America in the nineteenth century was the golden age of freedom. The point is not that Friedman doesn't realize many of these things, thinks racial inequality is no big deal, and so on. He mentions the "shame of slavery" a couple paragraphs later. Instead, it crystallizes Friedman's general tendency to ignore even his own ideas of freedom when they conflict with the freedom of individuals to spend money as they see fit.

This analysis threatens to undermine Friedman's entire philosophy of freedom. The central goal of his writings on freedom, from Capitalism and Freedom forward, is to convince liberals, progressives, and democratic socialists that democratic and political freedom cannot be divorced from economic freedom. He rejects, in both his conceptual and his practical writings, the idea "that any kind of political arrangements can be combined with any kind of economic arrangements" (Friedman, 1962, p. 7). In response to concerns for the ways that dependence and inequality threaten political and democratic freedom, then, it won't simply do for Friedman to respond, "Yeah? Well these things aren't actually that important." To do so would be to abandon this entire project, signaling what many philosophers and political theorists assume from the beginning: that his work on freedom is, at the end of the day, not worth serious consideration. Fortunately, Friedman offers one significant exception to his opposition to economic redistribution: his negative income tax proposal. He writes,

There is every reason to help the poor man who happens to be a farmer, not because he is a farmer but because he is poor. The program, that is, should be designed to help people as people not as members of particular organizational groups or age groups or wage-rate groups or labor organizations of industries. This is the defect of farm programs, general old-age benefits, minimum wage laws, pro-union legislation, tariffs, licensing provisions of crafts or professions, and so on in seemingly endless profusion. Second, so far as possible the program should, while operating through the market, not distort the market or impede its functioning. This is a defects of price supports, minimum-wage laws, tariffs, and the like (Friedman, 1962, p. 191). ${ }^{15}$

15 Interestingly, Friedman speaks favorably of a negative income tax despite the fact that "it establishes a system under which taxes are imposed on some to pay subsidies to others" and therefore presents "the danger that instead of being an arrangement under which the great majority tax themselves to help an unfortunate minority, it will be converted into one under which a majority imposes taxes for its own benefit on an unwilling minority" (Friedman, 1962, p. 194). 
Friedman's concern here is not promoting political freedom or democratic equality, but simply the alleviation of the most extreme forms of poverty. Moreover, while he supports and defends a negative income tax in a number of articles and interviews, he does so at times with a degree of ambivalence. He writes,

If we lived in a hypothetical world in which there were no governmental welfare programs at all and in which all assistance to the destitute was by private charity, the case for introducing a Negative Income Tax would be far weaker than the case for substituting it for present programs ... For such a world, I do not know whether I would favor a negative income tax - that would depend on how effectively private charity was in fact providing for the destitute (Friedman, 1968, p. 115).

As Friedman notes, however, that is not our world, nor is there the "remotest chance that it will be in foreseeable future" (Friedman, 1968, p. 115). The right, like the left, ought to support negative income tax in a non-ideal world where (1) it replaces many existing and counterproductive welfare measures and (2) where private charity may not be sufficient to meet the needs of the destitute. Here, Friedman inspires Charles Murray's recent argument for a guaranteed minimum income (Murray, 2006). For Murray and Friedman, a central argument for basic income is that it enables liberal societies to meet the basic needs of all citizens, without distorting the role that the price mechanism plays in efficiently allocating resources, as means-tested and other welfare state programs appear to. For Murray, the "practical necessity" that a basic income replace the existing welfare state is also "serendipitous. The real reason to scrap the advanced welfare state is that its apparatus is outmoded, ineffectual, and counterproductive" (Murray, 2008, p. 2). ${ }^{16}$

Friedman ought to drop any ambivalence, and give absolute priority to a negative income tax. Following the logic of his proposals for a flat tax (Friedman \& Friedman, 1980, pp. 306-307) and an economic bill of rights (Friedman \& Friedman, 1980, pp. 299-301), I suggest that Friedman and his followers support a constitutional amendment guaranteeing a substantial basic income, because of the challenges of achieving (and maintaining) such a bargain through the normal

16 Many criticize Murray's proposal. I will not defend it. My goal is not to defend a specific proposal, but to analyze Friedman's work on freedom, which ought to lead him, and likeminded followers, to give absolute priority to basic income in the status quo. That said, as I show in the remainder of the paper, not just any proposal will play the role that the negative income tax needs to play to redeem Friedman's theory of freedom. See (Munger, 2011) for further discussion of Murray's and Friedman's proposals. For an excellent overview of contemporary research on basic income, see (Widerquist, Noguera, Vanderborght, \& De Wispelaere, 2013). 
legislative processes. Such priority allows Friedman to accomplish many of his central goals. First, if it largely replaces the (on his view) increasingly ineffective and insultingly paternalist policies of the existing welfare state, such a basic income represents a clear step forward for both citizen's freedom and their welfare. According to Friedman, Herbert Kronsey “is surely right” when he claims that,

the people whose freedom is really being interfered with are the poor in Harlem, who are on relief. A government official tells them how much they may spend for food, rent, and clothing. They have to get permission from an official to rent a different apartment or buy secondhand furniture. Mothers receiving aid for dependent children may have their male visitors checked on by government investigators at any hour of the day. They are the people who are deprived of personal liberty, freedom, and dignity (Friedman, 1968, p. 111).

For some, including Friedman, unconditional basic income raises issues of exploitation and parasitism - where lazy people are content to live off the labor of others. Such concerns, however, are hardly unique to basic income. As James Buchanan argues, echoing Friedman, basic income is both more efficient and less likely to have rent-seeking problems than any other form of welfare state (Buchanan, 1997). ${ }^{17}$

Second, Friedman might ultimately consider democratic freedom (and economic freedom, for that matter) as only instrumentally valuable - as a time-tested way to further individual or aggregate welfare. For democratic freedom to be an effective instrument, however, to serve as a check on the concentrated power of economic elites who might restructure American political economy for their own benefit, and to address his lifelong interlocutors, he needs to provide an account for how liberal society can combat the ways in which economic inequality entails political domination. A negative income tax will assuage such concerns. Legislators may complement such a guaranteed income with other provisions, such as restrictions on campaign contributions, publically financed elections, and so on, aimed at preventing the economic sphere from corrupting the political sphere. The weaker such provisions are, the more robust a negative income tax needs to be. In the American context, where the Supreme Court has recently ruled that most limitations on campaign finance are unconstitutional, a quite substantial basic income is essential to mitigate political and economic domination and restore democratic legitimacy to

17 Like his fellow Nobel-Laureates Friedman and Buchanan, Herbert Simon celebrates the economic efficiency of basic income in combination with a flat tax. He also makes a provocative claim from justice that "When we compare the poorest with the richest nations, it is hard to conclude that social capital can produce less than $90 \%$ of income in wealthy societies like the United States or those in Northwestern Europe. On moral grounds, then, we could argue for a flat income tax of $90 \%$ that would return that wealth to its real owners” (Simon, 2001, p. 36). 
a system that is increasingly dominated by economic elites (Gilens \& Page, 2014). On its own, or in combination with other policies, such income must allow individuals not only to meet their basic needs, but also provide all citizens with at least some resources to use to influence the structures that, in Friedman's words, provide the "rules of the game" for their political and economic lives. After all, I doubt that Friedman or others would convince too many liberals and social democrats by simply referencing his ideal of a political economy with relatively little government involvement - claiming, in effect, that they shouldn't worry about political freedom and democratic legitimacy because, ideally, state actors won't make too many illegitimate laws. Giving absolute priority to a robust negative income tax allow him to actually address these interlocutors. ${ }^{18}$

Next, a negative income tax furthers the sort of effective freedom that, as I demonstrate above, brings Friedman's conception of freedom closer to Sen than classical liberals or libertarians such as Hayek and Nozick. In Sen's terms, basic income serves as a kind of "protective security" measure that plays both an intrinsic and instrumental role in furthering the freedom of citizens (Sen, 1999, p. 40). ${ }^{19}$ For Friedman, similarly, the absence of interference is not sufficient for political or economic freedom. Such freedom requires both access to resources and a number of similarly valuable alternatives. A negative income tax guarantees that all citizens possess (and control) such resources, even if they lack access to capital, or are unable to command gainful employment in the status quo. Fourth, an unconditional basic income redeems arguably the central claim of Friedman's political economy: that market exchange is non-coercive. Markets, he claims, are preferred to government intervention because in market exchange cooperation is achieved without coercion. To defend his claim that markets enable cooperation without coercion, Friedman describes a simple market model, where each household controls resources enabling it to produce goods or services directly for itself or for exchange. Due to specialization, there will be production for exchange, but,

Since the household always has the alternative of producing directly for itself, it need not enter into any exchange unless it benefits from it. Hence no exchange will take place

18 Which is not to claim that unconditional basic income on its own (however robust) would completely satisfy deliberative democrats concerned with unequal political influence.

19 Effective economic freedom for Sen and Friedman differs from "real freedom" as understood by Van Parijs. Neither Sen nor Friedsman, moreover, argue for basic income as a way of collecting "employment rents" of more fortunate workers (Van Parijs, 1998). Nonetheless, all three could agree that a form of basic income furthers the freedom of the unemployed or underemployed. Whether or not this makes them all "real libertarians" is not a concern of this work. 
unless both parties do benefit from it. Cooperation is thereby achieved without coercion (Friedman, 1962, p. 13).

According to Friedman, market exchange is effectively free because no individual must participate in it. To be certain, there are other ways to conceive of coercion. Friedman's non-coercive baseline differs from many prominent views in the liberal tradition (Nozick, 1969; Wertheimer, 1987). Nonetheless, it is intuitively compelling. When an individual is able to produce for herself, we have reason to believe that her choice to enter into an alternative productive arrangement is a free choice.

It is illuminating to highlight that Friedman's simple model, and the link between freedom and the ability to produce for yourself, recalls the central concerns that American "founding fathers" James Madison and Thomas Jefferson (whom he cites approvingly throughout Free to Choose) raised for an increasingly capitalist American republic. Jefferson, Madison, and other republicans spent much of their lives arguing that America remain primarily an agrarian economy of independent citizen farmers. A manufacturing or servicebased economy, they argued, would inevitably (a) corrode the virtues necessary for citizens of a democratic republic and lead to (b) material inequality that is incompatible with democratic self-government and (c) the dependence of even the most industrious workers on owners that made them easily manipulated (Sandel, 1998; Skinner, 1997). The economic growth of modern capitalism, they reasoned, was not worth the cost to their republican ideal of equal, virtuous, and independent citizenship. Jefferson and Madison did not deny the virtues of markets per se. Instead, they argued that the wage dependency that they understood as part and parcel of a capitalist society was incompatible with republican freedom. ${ }^{20}$ Such dependency, Jefferson writes in a quote frequently taken out of context, "begets subservience and venality, suffocates the germ of virtue, and prepares fit tools for the designs of ambition" (Jefferson, 1787 p. 290-291). ${ }^{21}$

20 Republicans understand freedom as non-domination, rather than the absence of coercion or interference. According to this conception, we are free to the extent that we do not find ourselves under the domination of others, subject to their will and exposed to changes in their whims and desires. Pettit writes, "Domination, as I understand it here, is exemplified by the relationship of master to slave or master to servant. Such a relationship means, at the limit, that the dominating party can interfere on an arbitrary basis with the choices of the dominated: can interfere, in particular, on the basis of an interest or an opinion that need not be shared with the person affected" (Pettit, 1997, p. 22). In recent work, Pettit presents an "eyeball test" for domination (Pettit, 2012, 2014).

21 On the relationship between capitalism and virtue they echo Adam Smith, whom Friedman cites even more frequently than Jefferson and the "founding fathers" in support of his claims 
The problem with Friedman's account is his attempt to use his model of individual, self-sufficient economic actors to redeem that claim that contemporary market exchange is coercion-free. Friedman writes,

As in the simple model, so in the complex enterprise and money-exchange economy, cooperation is strictly individual and voluntary provided: (1) that enterprises are private, so that the ultimate contracting parties are individuals and (2) that individuals are effectively free to enter or not enter into any particular exchange, so that every transaction is strictly voluntary (Friedman, 1962, p. 8).

Note, as C.B. Macpherson does (1973), what has changed from the simple model to the complex model. Previously only the ability to produce for yourself was sufficient to protect individuals from coercion. Now, Friedman suggests that the ability to not enter into a particular contract will do. The self-sufficiency that made Friedman's claim plausible in the earlier model is completely absent. So, too, is a central plank in Friedman's understanding of economic freedom: the idea that such freedom requires a number of more or less equally valuable options.

Fortunately, Friedman's negative income tax comes to the rescue here as well. ${ }^{22}$ In a society with a substantial, unconditional income through a negative income tax, individuals, as in the simple model, would not only be free to decline a particular offer of employment, but also not to work for another citizen at all. To accomplish this task, of course, negative income tax must be set at a level that enables citizens to meet their basic survival and citizenship needs ${ }^{23}$ without further income. Such a society could more plausibly be said to parallel Friedman's model of a market that enables cooperation without coercion. This discussion, furthermore, points us to a central way in which the concern for freedom in market society expressed by Jefferson and Madison overlaps with concerns for democratic equality. Republicans increasingly recognize that concerns for democracy and democratic legitimacy are essential to safeguarding

about freedom. Smith feared that the division of labor and corresponding technological innovation that drives the great productivity of modern exchange economies also adversely affects a worker's spirit and his capacity for moral judgment (Smith, 1776b, p. 368).

22 For more on republicanism and free markets, see (Lovett, 2009; Pettit, 2013).

23 "Basic needs," in other words, must be understood so as to include not only what is necessary for bare survival, but also meet what are sometimes referred to as the needs or interests fundamental for social agency. Otherwise, the negative income tax would fail to redeem Friedman's central claim that capitalism enables cooperation without coercion, and, absent existing protections, leave individuals less free than in the status quo. See (Schuppert, 2013) for a recent overview of the philosophical literature on basic needs. See (Preiss, 2014) for further normative analysis of autonomous or free (vs. unfree) exchange. 
republican liberty, to protect individuals from attempts by other agents to use the state apparatus itself to dominate others. Great inequalities of political power undermine legitimacy for both republican and democratic theorists (Pettit, 2012). With a robust negative income in place, however, liberals who understand freedom as the absence coercion and republicans who understand freedom as non-domination could join Friedman in advocating various reforms to tax and economic structures aimed at unleashing the power of free markets. Indeed, republicans sometimes mirror Friedman's instrumental defense of market freedom as a way of checking the arbitrary power of the state. As Pettit argues, "the republican tradition can join with the liberal and libertarian tradition in hailing the market for what it achieves" (Pettit, 2006, p. 134).

Even more strongly, Robert Taylor contends that "the proper republican attitude toward competitive markets is celebratory, not acquiescent, and that republicanism demands such markets for precisely the same reason that it demands the rule of law: because both are essential institutions for protecting individuals from arbitrary interference” (Taylor, 2013, p. 594). Republican celebration of free markets, however, is contingent upon a number of conditions. Markets must be competitive, rather than monopolist or monopsonist. From the perspective of workers, numerous exit options, and mutually understood contractual and customary rules, are essential to prevent workers being subject to the discretion and arbitrary will of employers (Taylor, 2013, p. 599). Taylor's republican understanding of worker freedom parallels Friedman's understanding of consumer freedom. For Friedman, monopolies threaten consumer freedom because "exchange is truly voluntary only when nearly equivalent options exist" (Friedman, 1962, p. 28). For Taylor, monopsonies threaten worker freedom because the acceptance of an offer is only free when numerous quality employment options exist. In case such options do not exist in a given locale, Taylor recommends that governments provide "relocation vouchers," and an unconditional basic income to "serve as a firm backstop against employment exploitation, discrimination, and domination by making it possible for workers to exit the labor market entirely" (Taylor, 2013, p. 597). ${ }^{24}$ I see no principled reason why Friedman should oppose relocation vouchers. His negative income tax, then, could serve as a form of unconditional basic income. Friedman's writings provide further support for economic institutions that safeguard republican freedom.

Taylor's republican celebration of free markets, finally, faces the same issue as Friedman's liberalism: will political and democratic support for universal basic income, and worker mobility vouchers, remain if, as he recognizes, his proposals further undermine the sort of union and labor power that has historically served

24 See also (Lovett, 2009, pp. 825-828; Pettit, 2007). 
as a countervailing force to business power (Taylor, 2013, pp. 599-600)? Taylor concludes that

\begin{abstract}
We should also be aware that these Anglo-Nordic economic policies are not a la carte: they must be implemented in tandem, because pursuing some in the absence of the others may increase rather than decrease domination. For example, a robust attack on union privileges without parallel efforts to diminish employer collusion in particular labor markets (e.g. hospital nursing) and enhance labor mobility may simply make workers more vulnerable to the market power of capitalists (Taylor, 2013, p. 601).
\end{abstract}

For this reason Taylor and other free market republicans, like Friedmanite liberals, must give absolute priority to a negative income tax or some form of unconditional basic income. ${ }^{25}$ As the analysis above indicates, the specifics of a negative income tax would and should vary according to a host contextual features, including health care costs, the availability of relocation vouchers, campaign finance laws, and so on. In the spirit of Friedman's pragmatism, it requires like-minded liberals and republicans to eschew a one-policy-fits-all approach to a basic income guarantee. In order to do the necessary work, however, such a proposal would need to (1) enable individuals to exit the workforce entirely (2) be more substantial the more other institutions allow wealth to lead to political and economic domination, and (3) insure that such basic income tracks inflation and changes in cost of living. The floor of the negative income tax, therefore, may very well need to exceed the Friedmaninspired, and purported revenue-neutral, proposals of Murray (\$10000) and Munger (\$16000 - \$12800 after taxes) to accomplish these goals (Munger, 2015; Murray, 2006).

Whether replacing much of the existing welfare state with a substantial basic income would, on the whole, further freedom for a republican or a deliberative democrat is a matter for another debate. My claim is that Friedman and like-minded liberals and libertarians should give absolute priority to his negative income tax proposal. ${ }^{26}$ Without such a negative income tax

25 While recognizing the possibility of exit as a step forward for freedom, some republicans argue, in the tradition of $19^{\text {th }}$ century labor republicans, for a transformation in the worker/ owner relationship to give workers greater say over the use of productive assets. Neorepublicans such as Pettit and Taylor, on this view, are insufficiently concerned with structural domination (Gourevich, 2013). It is doubtful that such labor republicans, absent a more democratic form of capitalism than the status quo, could join Taylor in supporting policies that significantly undermine the power of organized labor. While I am sympathetic to these arguments nothing in this paper requires taking a stance on this issue.

26 See (Powell, 2011; Vallentyne, 2011; Zwolinski, 2011) for an overview of classical liberal and libertarian theory and Universal Basic Income. 
securely in place, many attempts to eliminate the welfare state will, for reasons highlighted by Friedman's own arguments, make individuals less free. Finally, concerns for political domination provide further reason for Friedman and his supporters, as well as free market republicans, to support a constitutional amendment that makes such income as secure as possible. ${ }^{27}$ Making a negative income tax a (more) permanent part of the basic structure of American political economy will help to counter the ability of wealthy individuals to dominate the legislative process, ensuring a minimum threshold of political and economic freedom for all citizens, and further Friedman's argument that American capitalism enables cooperation without coercion.

\section{Conclusion}

This paper is primarily concerned with a conceptual analysis of Friedman's arguments for freedom. Friedman never defends his account of freedom, or the role of government in a free society, in terms of the self-ownership thesis. ${ }^{28}$ Without such a normative claim, Friedman must defend his unwillingness to acknowledge trade-offs between the absence of economic interference and other forms of freedom by telling something of a "just so" story. It just so happens that, in all of these cases, and in all contexts, that economic freedom as non-interference best promotes equality, opportunity, non-domination, democratic liberty, effective freedom, and so on. More modestly, while eschewing claims of selfownership, Friedman might simply argue that economic freedom as non-intervention generally produces good consequences. Both historically and conceptually, capitalism promotes liberty and the general welfare far better than socialism or any alternative economic arrangement.

This more modest claim is certainly more plausible than the "just so" story. Nonetheless, it doesn't really justify Friedman's unwavering commitment to freedom as economic non-interference. Nor does it resolve debates over how to best structure a given capitalist economy, including many of his proposed reforms. Even if we affirm Friedman's ideal state where government's involvement in the economy is strictly limited, this ideal does not address the ways in which economic inequality impacts a given individual's political freedom to

27 Even if the precise implementation and protection of such a right would vary from context to context.

28 As such, he is best understood as a classical liberal than a libertarian, as Tomasi and others understand of the terms (Tomasi, 2011). 
elect representatives and influence government on behalf of her values or interests, as well as the effective speech (which he considers the central aspect of civil freedom) of different individuals within society. In the status quo, where governments are far more involved in our social and economic lives than in his ideal, and where wealth and corporate ownership are very highly concentrated, such inequality enables a small economic elite to restructure the global political economy for their own benefit. Economic dependence, moreover, undermines his claim that markets enable cooperation without coercion.

For all of these reasons, I suggest a new priority. Any attempt to reconcile Friedman's proposals with his arguments for freedom, and to engage his lifelong interlocutors, must give priority to his proposed negative income tax. The language of generalities is the language of non-ideal theory. Since we can't expect either markets or governments to perform as they ideally would, we need to ask what sorts of policies generally protect and promote liberty. The central tenet of Friedman's non-ideal theory, on this understanding, is: do not undertake my other proposed reforms unless a substantial negative income tax, or some other form of basic income, is in place. Otherwise, such policies threaten to leave individuals less substantively free, dominated, coerced, and democratically impotent in a society in which the ability to influence the democratic process plays an important role in our freedom or well-being. The priority of basic income won't address all of the tensions highlighted above, but somewhat shifts the concern from Friedman himself, to those who propose such reforms in the context where individuals do not have secure access to a substantial basic income. With this central modification in mind, more philosophical and empirical work needs to be done to consider whether or not, and to what extent, the reforms Friedman spent most of his life championing have made people more free.

Acknowledgment: The author would like to thank Eric Schliesser and Eric MacGilvray for their helpful comments on previous drafts of this article.

\section{References}

Alverado, F., Atkinson, A., Piketty, T., \& Saez, E. (2013). The top 1 percent in international and historical perspective. Journal of Economic Perspectives, 27(3), 3-20.

Bartles, L. (2008). Unequal democracy: The political economy of the new gilded age. Princeton: Princeton University Press.

Berlin, I. 1958. Two concepts of liberty. Oxford: Clarendon Press.

Berlin, I. (1969/1990). Four essays on liberty. Oxford: Oxford University Press.

Buchanan, J. M. (1997). Can democracy promote the general welfare? Social Philosophy and Policy, 14(2), 165-179. 
Buchanan, J. M., \& Tullock, G. (1962). The calculus of consent: Logical foundations of constitutional democracy. Indianapolis: Liberty Fund.

Childs, D. 2006. Britain since 1945: A political history (6th ed.). London: Routledge.

Forst, R. (2011). The right to justification: Elements of a constructivist theory of justice. (J. Flynn, Trans.). New York: Columbia University Press.

Friedman, M. (1962/2002). Capitalism and freedom. Chicago: University of Chicago Press.

Friedman, M. (1968). The case for the negative income tax: A view from the right. In J. H. Bunzel (Ed.), Issues of American public policy. Englewood Cliffs, NJ: Prentice-Hall.

Friedman, M. (2005). Interview with Dallas Federal Reserve President and CEO Robert W. Fisher. October 19.

Friedman, M., \& Friedman, R. 1980. Free to choose: A personal statement. New York: Harcourt Inc.

Galbraith, J. K. (1952). American Capitalism: The Concept of Countervailing Power. Boston: Houghton Mifflin.

Gilens, M., \& Page, B. (2014). Testing theories of American politics: Elites, interest groups, and average citizens. Perspectives in Politics, 12(3), 564-581.

Gourevitch, A. (2013). Labor republicanism and the transformation of work. Political Theory, 41(2), 591-617.

Gutmann, A., \& Thompson, D. (1998). Democracy and disagreement. Cambridge, MA: Belknap Press of Harvard University Press.

Habermas, J. (1992). Moral consciousness and communicative action. (C. Lenhardt, \&

S. W. Nicholsen Trans.). Cambridge, MA: MIT Press.

Harvey, D. (2007). A brief history of neoliberalism. Oxford: Oxford University Press.

Hayek, F. A. (1960). The constitution of liberty. Chicago: University of Chicago Press.

Jefferson, T. (1787). Notes on the State of Virginia.

Leonhardt, D. 2011. The paradox of corporate taxes. New York Times, February 2011.

Lomasky, L. (1987). Persons, rights, and the moral community. Oxford: Oxford University Press. Lovett, F. (2009). Domination and distributive justice. Journal of Politics, 71(3), 817-830.

Macpherson, C. B. (1973). Democratic theory: Essays in retrieval. Oxford: Oxford University Press.

Mischel, L., Bivens, J., Gould, E., \& Shierholz, H. 2012. The state of working America (12th ed.). Washington, D.C.: Economic Policy Institute.

Munger, M. (2011). "Basic Income" is not an obligation, but it may be a legitimate policy choice. Basic Income Studies, 6(2), 1-13.

Munger, M. (2015). One and one-half cheers for a basic income gaurantee: We could do worse, and already have. Independent Review, 19(4), 503-513.

Murray, C. (2006). In our hands: A plan to replace the welfare state. Washington, D.C.: AEI Press.

Murray, C. (2008). Guaranteed income as a replacement for the welfare state. The social contract revisited. Oxford: The Foundation for Law, Justice, and Society.

Nozick, R. (1969). Coercion. In S. Morgenbesser, P. Suppes, \& M. White (Eds.), Philosophy, science, and method: Essays in honor of Ernest Nagel. New York: St. Martin's Press.

Nozick, R. (1974). Anarchy, state, and utopia. New York: Basic Books.

Nutter, G. W. (1951). The extent of enterprise monopoly in the United States, 1899-1939. Chicago: University of Chicago Press.

Pettit, P. (1997). Republicanism: A theory of freedom and government. Oxford: Oxford University Press.

Pettit, P. (2006). Freedom in the market. Politics, philosophy, and economics, 5(2), 131-149. 
Pettit, P. (2007). A republican right to basic income? Basic Income Studies, 2(2), 1-8.

Pettit, P. (2012). On the people's terms: A republican theory and model of democracy. Cambridge: Cambridge University Press.

Pettit, P. (2013). Taking back the economy: The market as a Res Publica. Our Kingdom: Power and liberty in Britain. Retrieved from http://www.opendemocracy.net/ourkingdom/ philip-pettit/taking-back-economy-market-as-res-publica

Pettit, P. (2014). Just freedom: A moral compass for a complex world. New York: Norton.

Piketty, T. (2013). Capital in the twenty-first century. Cambridge, MA: Belknap Press of Harvard University Press.

Piketty, T., \& Zucman, G. (2015). Wealth and Inheritance in the Long Run. Handbook of Income Distribution, Vol. 2. Amsterdam: North-Holland Press.

Powell, B. (2011). Two libertarian arguments for basic income. Basic Income Studies, 6(2), 1-10.

Preiss, J. (2014). Global labor justice and the limits of economic analysis. Business Ethics Quarterly, 24(1), 55-83.

Reich, R. (2007). Supercapitalism: The transformation of business, democracy, and everyday life. New York: Vintage Books.

Reitan, E. A. (2003). The Thatcher revolution: Margaret Thatcher, John Major, Tony Blair, and the transformation of Modern Britain, 1979-2001. Oxford: Rowman \& Littlefield.

Sandel, M. (1998). Democracy's discontent: America in search of a public philosophy. Cambridge, MA: Belknap Press of Harvard University Press.

Sen, A. 1999. Development as freedom. Oxford: Oxford University Press.

Sen, A. (2002). Rationality and freedom. Cambrdige, MA: Belknap Press of Harvard University Press.

Sen, A. 2009. The idea of justice. Cambridge, MA: The Belknap Press of Harvard University Press.

Shuppert, F. (2013). Distinguishing basic needs and fundamental interests. Critical Review of International Social and Political Philosophy, 16(1), 24-44.

Simon, H. (2001). Universal basic income and the flat tax. In P.Van Parijs (Ed.), What's wrong with a free lunch? Boston: Beacon Press.

Skinner, Q. (1997). Liberty before liberalism. Cambridge: Cambridge University Press.

Smith, A. (1776b/1982). The wealth of nations. Books IV-V. New York: Penguin Classics.

Stigler, G. 1949. Five lectures on economic problems. London: Longmans, Green, and Co.

Taylor, R. (2013). Market freedom as anti-power. American Political Science Review, 107(3), 593-603.

Tomasi, J. (2011). Free market fairness. Princeton: Princeton University Press.

Vallentyne, P. (2011). Libertarianism and the justness of basic income. Basic Income Studies, 6, 2.

Van Parijs, P. (1998). Real freedom for all: What, if anything, can justify capitalism. Oxford: Oxford University Press.

Wertheimer, A. 1987. Coercion. Princeton: Princeton University Press.

Widerquist, K., Noguera, J. A., Vanderborght, Y., \& De Wispelaere, J. (Eds.). (2013). Basic income: An anthology of contemporary research. Oxford: Wiley-Blackwell.

Zwolinski, M. (2011). Classical liberalism and the basic income. Basic Income Studies, 6, 2. 